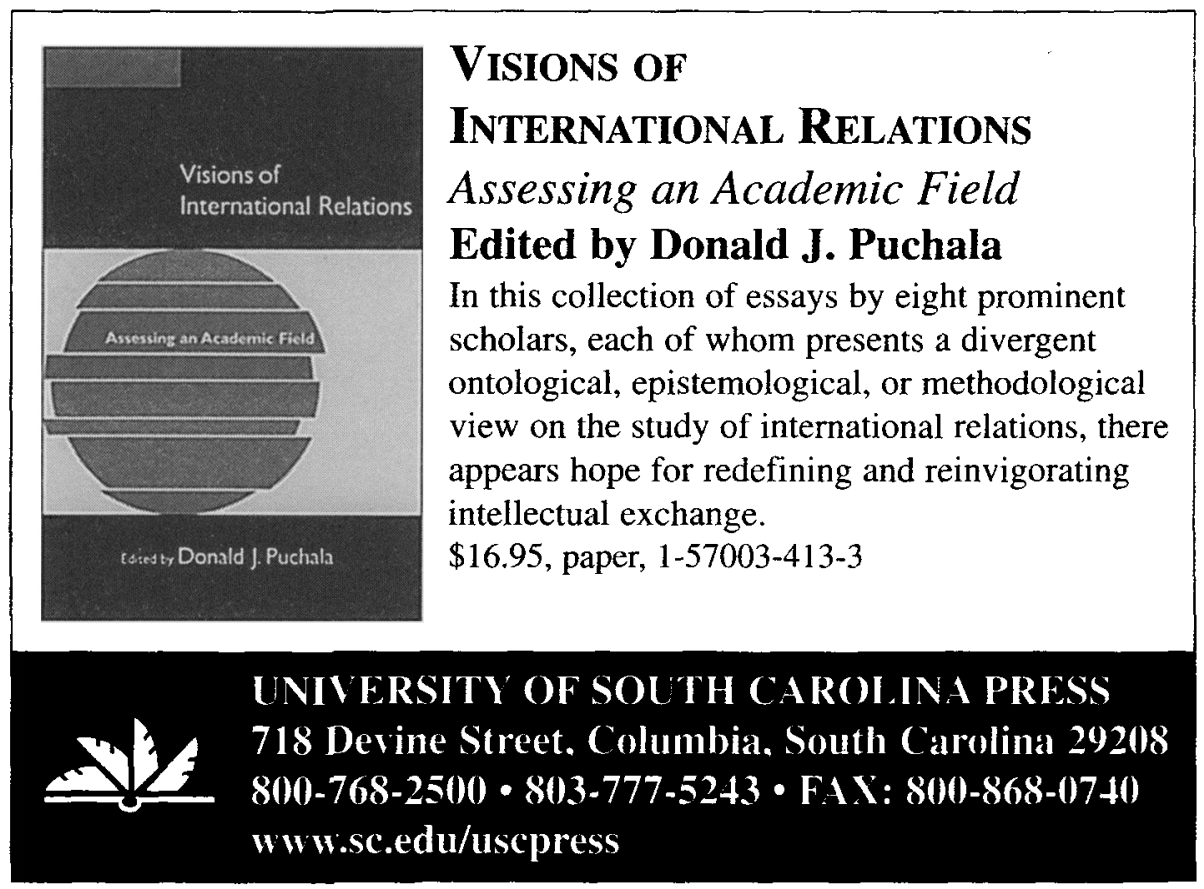


Legalization and World Politics

edited by Judith L. Goldstein, Miles Kahler,

Robert 0 . Keohane, and Anne-Marie Slaughter

An exploration of the intersection of international law and world politics from the viewpoints of the two disciplines. Intemational Organization Special issues

336 pp. $\$ 24.95$ paper

\section{The Health of Nations}

Infectious Disease, Environmental Change, and Their Effects on National Securtty and Development Andrew T. Price-Smith

"Will be known as the book on the political economy of disease for some time to come." - Dennis Pirages, University of Maryland 232 pp., 1 illus. \$22.95 paper

\section{Environmental}

\section{Leadership in}

\section{Developing}

\section{Countries}

\section{Transnational Relations} and Blodlversity Policy in Costa Rica and Bolivia Paul F. Steinberg

"By demonstrating the close links between domestic and international environmental leaders, the book demolishes the misleading myth that conservation is the

'foreigner's agenda."

- William Ascher.

Claremont McKenna College

272 pp., 32 illus. $\$ 24.95$ paper

\section{Zone Books}

now in paperback

\section{Crossing Boundaries}

\section{Selected Writings}

Albert $O$. Hirschman

Gathered here for the first

time in one volume are recent writings of interdisciplinary range, erudite sophistication, and limitless curiosity.

Distributed for Zone Books 112 pp. \$13.95 paper
Globalization and Environmental Reform

The Ecological

Modernization of the Global Economy

Arthur P. J. Mol

"Provides a stimulating analysis of ecological modernization in the context of globalization. . . the most important introduction to modern environmental policy yet published."

- Martin Jaenicke, Free University of Berlin

288 pp., 11 illus. $\$ 35$

\section{The Future}

of Turkish

\section{Foreign Policy}

edited by Lenore G. Martin

and Dimitris Keridis

"Turkish foreign policy has never before been treated from such a different angle and by such competent authorities."

- Mehmet Ali Birand, writer, analyst on Turkish Affairs CNN 300 pp. $\$ 23.95$ paper

now in paperback

\section{Without a Map}

Political Tactics and

Economic Reform in Russia

Andrei Shleifer

and Daniel Treisman

"Makes a significant contribution to the ongoing debate about Russian reforms."

- itzhak Goldberg

and Lev Freinkman,

Finance and Development

240 pp., 9 illus. $\$ 15.95$ paper

\section{Offense, Defense, and War}

edited by Michael E. Brown, Owen R. Coté, Jr.,

Sean M. Lynn-Jones, and Steven E. Miller

An overview of offensedefense theory, which presents contending views and the most recent attempts to refine and test the theory.

An international Security Reader 401 pp. \$24.95 paper

\section{new from the mit press}

\section{Russian Strategic Nuclear Forces}

edited by Pavel Podvig foreword by Frank von Hippel

"Will be a critical resource for scholars and policy makers because of its carefully documented and thorough analysis of the Soviet/

Russian nuclear complex and weapons." - Bradley Thayer, University of Minnesota 620 pp. 57 illus. $\$ 45$

\section{International Relations and Global Climate Change}

edited by Urs Luterbacher and Detlef F. Sprinz

"Gathers together a variety of approaches from the field of international relations to explore the development of the climate change regime. It fills a niche that surprisingly no other book has filled." - Marvin Soroos, North Carolina State University 328 pp., 7 illus. $\$ 25$ paper

\section{Environmental \\ Regime Effectiveness}

Confronting Theory

with Evidence

Edward L. Miles,

Arild Underdal,

Steinar Andresen,

Jørgen Wettestad,

Jon Birger Skjærseth, and Elaine $M$. Carlin

"Breaks new ground in the study of international institu. tions and develops arguments that will undoubtedly stimulate additional research."

- Oran R. Young, Dartmouth College

512 pp., 10 illus. $\$ 29.95$ paper

To order call 800-356-0343

(US \& Canada) or $617-6258569$.

Prices subject to change without notice.

http://mitpress.mit.edu 


\section{Political Parties and Democracy}

\section{edited by Larry Diamond and Richard Gunther}

Are political parties in decline, or are they simply changing their forms and functions? In contrast to authors of most previous works on political parties, which tend to focus on longestablished Western democracies, the contributors to this volume cover many regions of the world. As the authors show, political parties are now only one of many vehicles for the representation of interests, but they remain essential for recruiting leaders, structuring electoral choice, and organizing government. To the extent that parties are weak and discredited, the health of democracy will be seriously impaired.

A Journal of Democracy Book

$\$ 18.95$ paperback

\section{European Defense Cooperation}

Asset or Threat to NATO?

Michael Quinlan

"This book offers seasoned judgments by an authoritative British observer regarding a topic central to the future of both NATO and the European Union. It will make an important contribution to public understanding of the issues on both sides of the Atiantic."-David S. Yost, U.S. Naval Postgraduate School, author of NATO Transformed: The Alliance's New Roles in International Security

Woodrow Wilson Center Press

$\$ 11.95$ paperback

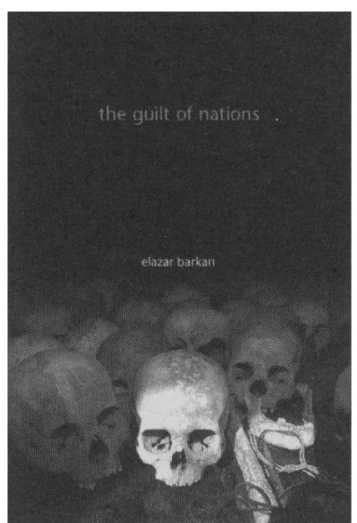

\section{The Guilt of Nations}

Restitution and Negotiating Historical injustices

\section{Elazar Barkan}

"Well-researched and discriminating." -Michael Ignatieff, New York Times Book Review

"Both an invaluably detailed catalog of various groups' past and present claims for restitution and a theoretical consideration of the idea's practicality and morality, this book will no doubt take its place as the starting point for a full understanding of these highly complex issues."-Jonathan Groner, Salon

"A remarkably lucid and even-handed account . . Barkan makes a persuasive case that, despite all the difficulties, the recent vogue for apologies and restitution should be welcomed." -The Economist

$\$ 18.95$ paperback 


\section{European Journal of International Relations}

\section{Published under the auspices of the Standing Group on International Relations of the ECPR}

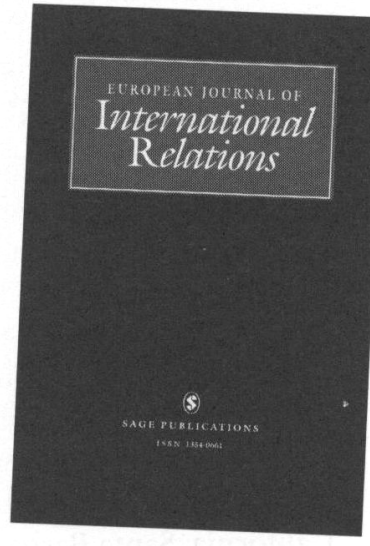

\section{Editor}

Friedrich V Kratochwil Ludwig-Maximilians-Universität, München, Germany

"EIR has already established itself as a world-class journal, one of the four or five in the field that are essential reading for scholars in international relations."

\section{Chris Brown}

"One of the best academic journals in international relations. The articles address a wide variety of theoretical positions and issues, and the national diversity of its authors exceeds that of any other important journal in the field." Mark Zacher

"The most important new academic journal on international affairs to have appeared in recent years. The journal's pluralistic approach to theoretical, methodological, and substantive issues in international relations represents a unique contribution to the field." Thomas Risse

"An indispensable tool for everyone interested in innovative IR theory and research." Emanuel Adler

...stimulates and disseminates the latest research in international relations. The journal addresses methodological and epistemological questions as well as conceptual and empirical developments within the major sub-areas of the field.

Quarterly: March, June, September, December (ISSN: 1354-0661) Introductory Rate for Individuals $£ 33 /$ US $\$ 52$ (Usual Rate £42/US\$66) Institutional Rate £240/US\$377 


\section{Banking on Stability}

Japan and the Cross-Pacific Dynamics of International Financial Crisis Management

Saori N. Katada

"Focusing on the role of Japan as a major but nonhegemonic power, Saori Katada skillfully weaves together structural and domestic explanations for variations in the commitments of key governments to effective collective action.... Must reading for students of both international and political economy and Japanese public policy." -Benjamin Jerry Cohen, University of California, Santa Barbara

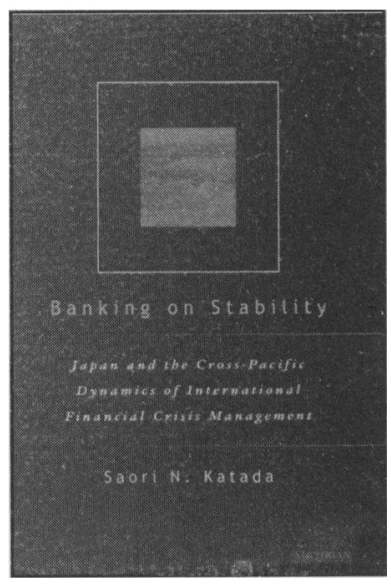

cloth $\$ 49.50$

\section{Rebellious Civil Society}

Popular Protest and Democratic Consolidation in Poland, 1989-1993

Grzegorz Ekiert and Jan Kubik

"An important contribution to the literature on emergent democracies in Central and Eastern Europe."

- Contemporary Sociology

Winner of the 2000 AAASS/Orbis Books Prize for Polish Studies.

Now in paper $\$ 22.95$

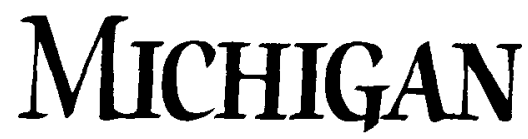

The University of Michigan Press Dept. SG Ann Arbor, Michigan 48106-1104

\section{Democracy without} Associations

Transformation of the

Party System and Social

Cleavages in India

Pradeep K. Chhibber

"An ambitious study of one of the most important topics in contemporary South Asian politics. Its historical scope and the range of public-opinion data which it examines make a unique contribution to the literature...."-Australian Journal of Political Science

Now in paper $\$ 24.95$

Credit card buyers may order by phone (734-764-4392) or by fax (800-876-1922). www.press.umich.edu 


\section{Out of the Red}

Building Capitalism and Democracy in Postcommunist Europe

Mitchell A. Orenstein

This comprehensive parallel study of two critical East-Central European transition economies-Poland and the Czech Repuliclooks at the significance of reform mistakes and the corrective benefits of changes in policy.

cloth $\$ 54.50$ paper $\$ 22.95$

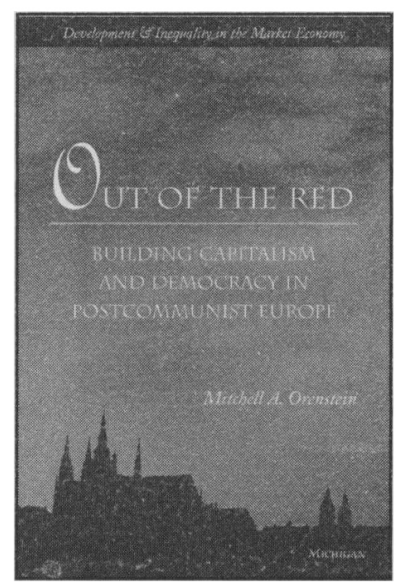

\section{After the Deluge}

Regional Crises and Political

\section{Consolidation in Russia}

Daniel S. Treisman

"This collection not only provides a snapshot of important institutional development during the El'tsin period but poses the provocative questions that will inform scholarship as Russia struggles to define itself in the future." - Slavic Review

Now in paper $\$ 21.95$

\section{Intellectuals and the} Articulation of the Nation

Ronald Grigor Suny and

Michael D. Kennedy, Editors

An interdisciplinary look at the role of the intellectual elite in the shaping of nations.

Now in paper $\$ 27.95$
Economic Reforms in Chile From Dictatorship to Democracy

Ricardo Ffrench-Davis

An analysis of the Chilean economic reform, from the military dictatorship of Pinochet in the 1970s to the "reform of reforms" made by democratic governments in the 1990s.

cloth $\$ 57.50$

\section{Compound Dilemmas}

Democracy, Collective Action, and Superpower Rivalry

Michael D. McGinnis and John T. Williams

Explores how domestic support for U.S. defense expenditures was generated during the arms race that marked the Cold War period.

cloth $\$ 57.50$ 


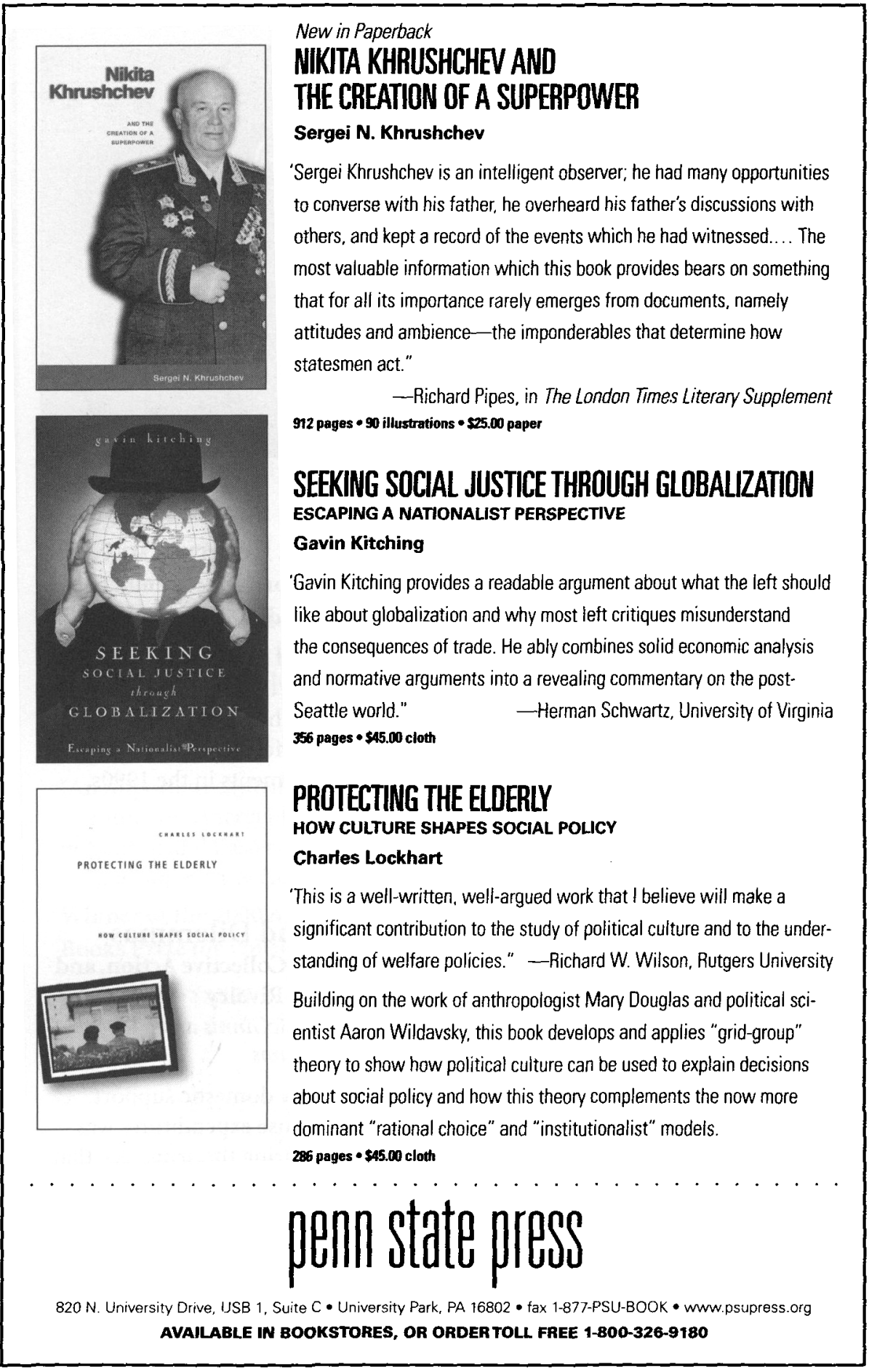

